\title{
Quality and Customer Loyalty in Islamic Banks: Religiosity as a Moderator by using Andrew Hayes model
}

\author{
Mohsin Shahzad ${ }^{1}$, Muhammad Shaukat Malik ${ }^{2}$, Muhammad Irfan ${ }^{3}$ \\ ${ }^{1}$ MSBA, Institute of Banking and Finance, Bahauddin Zakariya University, Multan \\ ${ }^{2}$ Professor \& Director, Institute of Banking and Finance, Bahauddin Zakariya University, \\ Multan \\ ${ }^{3}$ Assistant Professor, Institute of Banking and Finance, Bahauddin Zakariya University, \\ Multan \\ Email: mohsinshahzad5050@gmail.com
}

\begin{abstract}
The preservation of desired levels of service quality, product quality and awareness is domineering for firms to stay competitive. Islamic banking system of Pakistan is more growing and become popular that provide the products with the premises of Sharia compliance, but there is problem in this sector is lack of knowledge about the products. Findings relay on data collected through surveys of 300 customers of south Punjab Islamic banking sector. Through the respondent's opinions, our study revealed that service quality and product quality have significantly relationship with customer satisfaction and loyalty. There is shortage of familiarity about Islamic banking products to the customers and this caused to low satisfaction. Proper information is highly required in this sector to create patronize customers. More findings exposed that customer satisfaction positively indicates to customer loyalty and by using the Andrew Hayes method religiosity only moderates between service quality and customer satisfaction because religiosity is not the sole factor to satisfy the customers without proper information system about products. To maintain the competitive edge there is highly required proper brochures system in every branch with easily access to the customers for more convenience.
\end{abstract}

Keywords: Service Quality, Product Quality, Awareness, Customer Loyalty, Islamic banks, Religiosity

\section{Introduction}

Every nation has a religion to follow the rules that include in their religion. There are many religions in all over the world but Islam is one of the best religion that has prominent place in all over the world and the majority exist in world is Muslim. Every religion has its 
own rules and regulations for their followers to follow these rules and spent their lives. Islam has also the rules and principles that give the right path to us for spending our lives with best way. In Islam the haram things are prohibited by the sharia compliance like interest is prohibited by our Prophit Hazrat Muhammad (PBUH). Islam has some parameters those measure our all life with ethics and that's why the Muslim people especially in Pakistan the people of our country more prefer to religion because they are the true followers of the Islam. Manzoor, M., Aqeel, A. (2010) said that religion is the basic growth of Islamic banking sector in Pakistan. In Pakistan previous researches are explained that religiosity is favorable tools to intension toward Islamic banking. Because the Pakistani people mostly are the followers of the Islam so, they are avoid the haram things that dislike in Islam. Basically the riba system is haram in our religion whenever the conventional banking system give only the haram things more because of only talk of interest. But in the Islamic banking system there is strict system of monetary policy that disallow the riba and allow the trade only that is halal in our religion. Yousaf, Salman, and Muhammad Shaukat Malik, (2013). Religious factors also effect on Islamic banking system because this system was founded by the name of Islam. All Muslim customers will prefer this system and visit more time instead of conventional banking system. Islamic banking system is also best for the economic stability of any country. According to Majeed, M. T., \& Zainab, A. (2017) Islamic banks are causal to social welfare and all countries in over the world use the banking system to stable their economic procedure and to improve their inflation and deflation. Pakistan is a prominently a Muslim that containing 95 percent people the basic followers of the Islam. Now in Pakistan, also many Islamic windows by conventional banks are dealing with customers. Through statistical data of state bank of Pakistan as at the end of 2017, the Islamic banking sector contained of 21 Islamic banks; 5 full- fledged Islamic banks and 16 conventional banking system having stand-alone Islamic banking branches and total aggregate number of Islamic banking branches reached 2581 with the addition of more 213 branches. Total stand-alone Islamic banking branches that run by conventional banking was recorded 1277 branches. The total deposits of Islamic banking sector and market shares of assets increased 12.4 percent and 14.5 percent. The profit of Islamic banking industry was recorded 23 billion that increased from 17 billion at the end of (2017). (Bulletin, October-December 2017).

Different researchers consider that a modified marketing policy is vital for this system to expand service quality Faridah S., \& Melewar, T. C. (2013). Furthermore, service quality is the culture vise phenomena change due to the change of culture many researchers 
accept the PAKSERV scale to measure the with best. Basically, Pakistan has its own culture and this scale meets all perspectives of our country. Every organization should have the best quality of services to patronize their customers so, Islamic banking sector also has best quality of services to attain competitive edge. Service quality is the marketing tool that use in business and to improve their sale and this one is not enough for organization to sustain in market also some others strategies that are highly vital like; product quality and the best knowledge about the Islamic banking products, it means proper awareness system is also very important in this sector. Servicing with high product quality to the customers is the main achievement to any organization and also in Islamic banking it should be necessary to keep this strategy and use for the large profit and good will. The success of any product and service highly depends on customer acceptance and satisfaction Bashir, M. S., Machali, M. M., \& Mwinyi, A. M. (2012)

Our study explores the impact of service quality, product quality and awareness on customer loyalty through customer satisfaction and moderating effect of religiosity. In Pakistan not work on the product quality and product awareness impact on customer satisfaction and loyalty just work on the service quality in Islamic banking. Product quality and awareness are the main factors both Islamic as well as in conventional banking system because both banking system have most of the products provide same in nature to the customers. Conventional banking system is the direct competitor of Islamic banking system. The Islamic banking products and services must to be parallel or better than conventional banks and for all this purpose Islamic banks need to serve their consumers by addition of more values in quality and also should use the unique techniques to aware these products among the customers and convince them to patronize. In Pakistani Islamic banking sector, there is lack of these effective strategies and work done only service quality not on product quality nor on awareness for to produce loyal customers. 
The Objectives of the study are to observe the relationship between service quality, product quality and customer awareness on customer loyalty, to determine the impact level of mediating role of customer satisfaction between service quality, product quality and customer awareness on customer loyalty and to know the effect level of religiosity (Interpersonal religiosity, intrapersonal religiosity) between service quality, product quality awareness and customer satisfaction in Pakistani Islamic banks.

Research Questions are as follows;

- What are the Product quality, Service Quality and awareness, impact on customer loyalty?

- What is the Customer satisfaction link between Product quality, Service Quality and awareness with customer loyalty?

- What religiosity influence the relationship of product quality, service quality and awareness with customer satisfaction?

- What type of influence between product quality, awareness, service quality and customer satisfaction in Islamic banking sector of Pakistan?

- What type of relationship exist between customer satisfaction and customer loyalty in Islamic banking of Pakistan?

The purpose of this study will provide useful information for Business to help develop an effective marketing strategy to promote service quality, product quality and awareness ultimately increase profitability and get a competitive advantage. So this study is useful for managers and top level of decision makers that will use these unique strategies in future and create rebuying customers.

\section{Literature Review}

The excellence of the performance and to subjective goes Service quality Zeithaml, V. A., et al., (2011). The minor change in customer expectations and perceptions has been endorsed to best quality of service Kassim and Abdullah, (2010). Ennew, \& Waite, R. (2013) have identified that "service quality is a subjective and therefore, service quality is based on the customer's perception of how well the service matches their needs and expectations. In the study of Ago, G., Suharno, S. M., \& Hariyadi, S. (2015) product quality is defined as "overall nature characteristics of a product, which effect the ability to satisfy the tangible and intangible needs". Ahmad, S. A., \& Al, A. H. (2017) in this study the author explored the definition "Customer awareness is created majority by promotion and this is the function of informing, persuading and influencing the customer's decision process and this strategy is 
closely related to process of communication". Bowman, N. A.\& Park, J. J. (2016) endorsed that Awareness "being aware of issues to race, ethnicity, diversity, inequality and privilege".

Different researchers defined the customer loyalty with divided into two definitions: behavioral and attitudinal loyalty. "Behavioral loyalty denotes to a customer's behavior to repurchase because they like the same brand and service" Jiang, L., \& Yang, Z. (2016). "Attitudinal loyalty describe as the sensitive and psychological wishes of the customer to repurchase and recommended to the others". The researchers (Moon, S. (2011) defined that "The expectations from previous engrossment with the invention itself or with parallel products, other marketing enticements, current approaches and sureness felt by customer". "Customer satisfaction is an originator of customer loyalty and the process of service to complete and fulfill the expectations of the consumer" Rahi, S., \& Ghani, M. (2016). Wilson, A., Zeithaml, D. D. (2012) recognized that "satisfaction and dissatisfaction is an evaluation of a product and service offered to meet customers' needs or expectations". In the study of Usman, H., Tjiptoherijanto, I. G. N. (2017) the author denotes the religiosity, "as a degree of belief in God and followed by believing and practicing principles set forth". Abou-Youssef, M. \& El-Bassiouny, N. (2015) described "Religiosity is a fundamental derivative of religion".

\subsection{Service Quality and customer Satisfaction}

According to some researchers Ashraf, M. G. (2014), Alsayyed, N. M., Suifan, T. S., \& Alawneh, A. R. (2015), Janahi, M. A., \& Al Mubarak, M. M. S. (2017) there is confident association between service quality and customer satisfaction. Kashif, M., Abdur Rehman, M., \& Pileliene, L. (2016) Examine that there is a satisfaction level exist in Pakistani Islamic banking customers from the service quality offered. In this study, author found all dimensions of PAKSERV significantly subsidize with customer satisfaction and loyalty. Alnaser,, S. (2018) contributed that, service quality (PAKSERV) model has been significant relationship with customer satisfaction and customer loyalty. But here the contrast Xu, L., V. (2017) have different results that represent service quality has not been significant relation with customer satisfaction.

\subsection{Service Quality and Customer Loyalty}

Jahanshahi, Khaksar, S. M. S. (2011) discovered that service quality is innate factor for customer loyalty. There is high positive correlation between service quality, product quality, customer satisfaction and customer loyalty. Marković, S., Jelena, D., \& Katušić, G. (2015, January) described quality relates to direct loyalty. Mohamad, H. A. D. \& Azam, S. F. (2017) conclude that study is significant impression with service quality on customer 
satisfaction and customer loyalty in hotel industry. Same as Jeong, Y., \& Lee, Y. (2010) said that the product quality of service quality positive relate to the customer satisfaction and also loyalty in furniture purchaser. Kashif, M. \& Sarifuddin, S. (2015) accepted through his study that service quality greatly participate and positively influence on customer satisfaction and loyalty in Malaysia.

\subsection{Product Quality and Customer Satisfaction}

Rasheed, H., \& Wang, A. (2012) stated that, there is a positive affiliation between product quality and service quality on customer consummation. Xu, L., Blankson, C., \& Prybutok, V. (2017) explored that the service quality does not significant relationship with customer satisfaction but the product quality significantly influence on customer satisfaction in auto mobile industry. Saini, Y., Bick, G., \& Abdulla, L. (2011) showed that sole religiosity is inadequate to this sector. Others important elements would be used like quality of product, location of branch, awareness to the products and convenience are also the very attractive tools to attract the customers and become satisfied customers. Golder,, \& Moorman, C. (2012) also described that high product quality is attribute to the customer satisfaction and satisfaction with safety product.

\subsection{Product Quality and Customer Loyalty}

Different researcher have same research on product quality like; Jahanshahi, A. A., Gashti, M. A. H., Mirdamadi, S. A., Nawaser, K., \& Khaksar, S. M. S. (2011) and Atiyah, L. (2016) have explored that product quality does significantly relationship with customer satisfaction and leads to customer loyalty. Chalotra, V. (2012) has demonstrated that the high safety product relates to the customers satisfaction and also customer loyalty in small industries. Chai, K. H., Ding, Y., \& Xing, Y. (2009) conveyed that product quality effects customer satisfaction and loyalty in mobile phone industry.

\subsection{Awareness and Customer Satisfaction}

Many researchers have resulted that awareness is crucial for customer satisfaction like; Mohiuddin, Z. A., Begum, R., \& Rizvi, F. Z. (2018), I., Ahmad, N., Naveed, A., \& Ahmed, Z. (2018) and Jameel, S. A. (2017) have explained that due to unaware the customers from Islamic banking products these consumers were not satisfied and they were less attractive to the Islamic banking sector. They are conscious about the products that give the Islamic banks to the consumers. Jinjiri Ringim, K. (2014) reported that religion is the primary source to motivate the customers but in Islamic banking sector the religion is not enough due to tough competition with conventional banking. Doraisamy, \& Raman, R. (2011) proved that 
customers of Malaysia have acknowledged about Islamic banking products and leads to satisfaction level. According to (Bashir, M. S. (2013) the awareness is positively relationship with customer satisfaction in Brunei's Islamic banking.

\subsection{Awareness and Customer Loyalty}

Rammal, H. G., \& Zurbruegg, R. (2016) resulted that the majority of respondents in Australia were interested to Islamic banking product and want to become the loyal customers through the these products but the main problem is that only credited facility they knew and used by the customers. Buchari, I. \& Al Qassab, M. A. H. (2015) discussed that the knowledge of the employee of Islamic banking attributes to product quality may more attract customers to Islamic banking. Quran and Sunnah also stated with employee and they know about the products better and attract the consumer to their products. Thus above majority of the studies are saying that the awareness is unique element of marketing strategies. Jing, Z., \& Shabbir, R. (2014) have confirmed that brand awareness was positively relation with customer's loyalty.

\subsection{Customer Satisfaction and Customer Loyalty}

Several studies have same results of customer satisfaction to customer loyalty like; Ladhari, R., Souiden, N., \& Ladhari, I. (2011) and Rehman, M. A., \& Sarifuddin, S. (2014) have confirmed that the customer satisfaction significantly and positively impact on customers loyalty. Amin, M., Isa, Z., \& Fontaine, R. (2011) this study contributes that customer satisfaction enhance the customers loyalty in Muslim and non-Muslim consumers. Kitapci, O., Taylan Dortyol, I., Yaman, Z., \& Gulmez, M. (2013) conveyed that in super market customers of Turkey were satisfied from service quality and loyal. Amin, M., Isa, Z., \& Fontaine, R. (2013) studied that customer satisfaction significant relation with customer loyalty.

\subsection{Role of Religiosity}

Different researchers have confirmed with same studies on religiosity moderates like as; Saqib, L., Farooq, M. A., \& Zafar, A. M. (2016), Amin, M., Isa, Z., \& Fontaine, R. (2013) and Abou-Youssef, M. \& El-Bassiouny, N. (2015) have confirmed that Sharia Compliance has been significantly moderate between service quality and customer satisfaction. Wahyuni, S., \& Fitriani, N. (2017) exposed that religiosity as appreciated cause in marketing strategies for Indonesia Islamic banking. Religiosity proved as a positive sign of saving the customer in Islamic banking. Kaabachi, S., \& Obeid, H. (2016) studied that religious beliefs are positively impact on to use the Islamic banking products. Souiden, N., \& Jabeur, Y. (2015) checked that 
Islamic beliefs (Religiosity) moderate the relationship between attitudes and purchase intentions of the customer in Islamic banking sector.

\section{Theoretical Framework}

Figure 1

$\mathrm{H}$

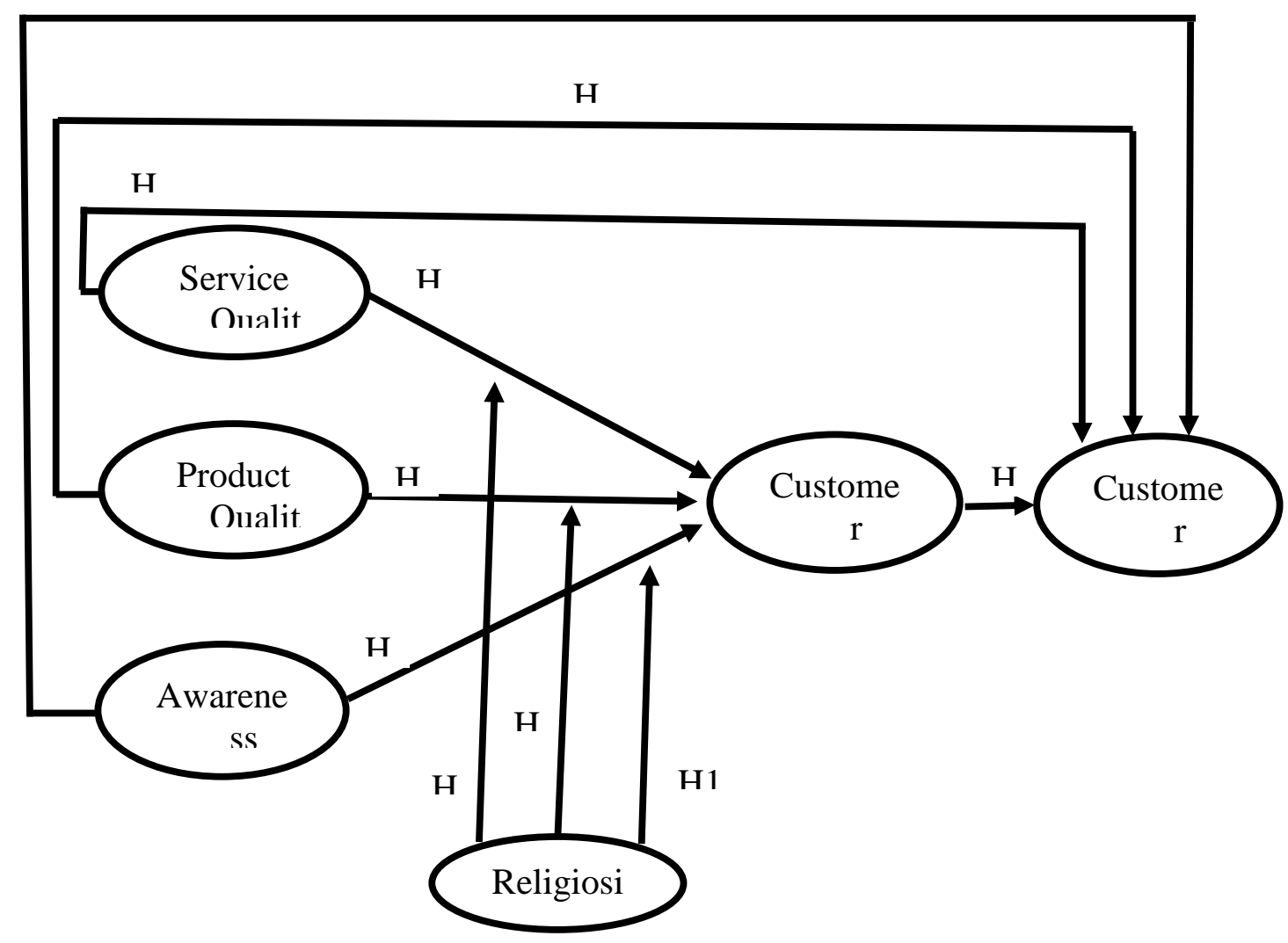

\subsection{Hypotheses}

H1: Service Quality is significantly contributes to Customer Loyalty.

$\mathrm{H} 2$ : Product Quality is significantly contributes to Customer Loyalty.

H3: Awareness is significantly contributes to Customer Loyalty.

H4: Service Quality is significantly contributes to Customer Satisfaction.

H5: Product Quality is significantly contributes to Customer Satisfaction.

H6: Awareness is significantly contributes to Customer Satisfaction.

H7: Customer satisfaction strongly influences Customer Loyalty.

H8: Religiosity moderate the relationship between Service Quality and Customer Satisfaction. H9:Religiosity moderate the relationship between Product Quality and Customer Satisfaction. H10: Religiosity moderate the relationship between Awareness and Customer Satisfaction. 


\subsection{Operationalization of Variables}

There are three independent variables in our study. First independent variable that is the service quality, the instruments adopted from Kashif, M., Wan Shukran, S. S., Rehman, M. A., \& Sarifuddin, S. (2015). Second independent variable is product quality, the instruments of this variable adopted from Ahmad, S. A., \& Al-Aidaros, A. H. (2017). A third independent variable is Customer Awareness, the instruments of this independent variable also adopted from Ahmad, S. A., \& Al-Aidaros, A. H. (2017). Basically the purpose of these independent variables is to measure the relationship between these variables and customer loyalty through the mediating role of customer satisfaction.

\section{Research Methodology}

This study is cross sectional and also contains in non-contrived environment. Because our study is in natural environment not in contrived environment that is basically an artificial environment like, a lab experiment etc. Our study is cross sectional because, we have obtained data in one shot. Basically, our research is a causal study that is to find out the cause and effect between variables. In our research work the target population are the customers of Islamic banking in Pakistan from south Punjab. There are forty six questions in our five point's likert scale questionnaire that, we have used in our survey. In sampling technique, we have adopted the probability sampling technique in our study because in probability sampling each element of the population have a same chance of being designated as a subject, furthermore in non-probability sampling we have choose convenient sampling because our topic respondents are the customers of Islamic banking. The sample size is 300 respondents of Islamic banking customers from south Punjab of Pakistan. Our target respondents are only the account holders of Islamic banking like as Meezan bank, Bank al Islami and Dubai Islamic banks and others full-fledged Islamic branches and also stand-alone branches. They all were the customers of Islamic banking sector different cities of Pakistan from south Punjab. SPSS is the basic software for findings correlations between variables. Mostly of the scholars recommends to use SPSS at the initial level of primary data analysis so, this is the reason that we have choosed SPSS, because our data is based on primary.

\subsection{Reliability test of scale}

In the above table I results indicate that all variable cronbach's alpha is greater $>0.7$. It means all the variables used in this study are highly reliable and significant. 
Table 1: Result for Reliability Analysis

\begin{tabular}{|c|c|c|c|}
\hline Variables & Cronbach's alpha & F (sig) & Item's \\
\hline Service Quality & 0.849 & $46.057(.000)$ & 21 \\
\hline Product Quality & 0.746 & $98.072(.000)$ & 4 \\
\hline Awareness & 0.777 & $55.147(.000)$ & 4 \\
\hline Customer Satisfaction & 0.792 & $40.456(.000)$ & 3 \\
\hline Customer Loyalty & 0.780 & $17.993(.000)$ & 3 \\
\hline Religiosity & 0.724 & $388.343(.000)$ & 10 \\
\hline
\end{tabular}

\section{Results And Discussion}

\subsection{Correlation Analysis}

Table 2: Correlation Model

\begin{tabular}{|l|l|l|l|l|l|l|}
\hline \multicolumn{1}{|c|}{ Variables } & $\mathbf{1}$ & $\mathbf{2}$ & $\mathbf{3}$ & $\mathbf{4}$ & $\mathbf{5}$ & $\mathbf{6}$ \\
\hline Service Quality & 1 & & & & & \\
\hline Customer Satisfaction & $.589^{* *}$ & 1 & & & & \\
\hline Customer Loyalty & $.505^{* *}$ & $.715^{* *}$ & 1 & & & \\
\hline Religiosity & $.286^{* *}$ & $.220^{* *}$ & $.168^{* *}$ & 1 & & \\
\hline Product Quality & $.514^{* *}$ & $.382^{* *}$ & $.378^{* *}$ & $.115^{*}$ & 1 & \\
\hline Awareness & $.127^{*}$ & -.081 & $-.032^{*}$ & $-.015^{*}$ & $.013^{*}$ & 1 \\
\hline
\end{tabular}

Note: $\mathrm{N}=300,{ }^{*} \mathrm{p}<0.05, * * \mathrm{p}<0.01 * * * \mathrm{p}<0.001$

In this table present the correlation analysis among the variables used in this study. The correlation results indicate each variable is correlated with each other because the value of correlation coefficient is on $(\mathrm{r}=1)$. Result shows in this table indicate that awareness significantly negative correlated with customer satisfaction, customer loyalty, and religiosity. It means decrease in customer satisfaction, customer loyalty and religiosity due to increase in awareness. And all remaining variables positively significantly correlated with each other. It means increase in one variable due to increase in other variable

\subsection{Result of regression analyses of service quality, product quality and awareness} for customer loyalty

In this table IV service quality $\mathrm{R}^{2}=0.77$. It means 77 percent variation in customer loyalty due to conversion in service quality. 6.8 percent change in customer loyalty due to change in Product quality the value of $\mathrm{R}^{2}=.068$. The value of $\mathrm{R}^{2}=.047$ of awareness indicate that the 4.7 percent change in customer loyalty due to change in awareness.

In the above correlation the value $\mathrm{P}<0.05$ and is 0.000 that means there is a substantial link between service quality and customer loyalty. From this result my study first hypothesis is approved. In the correlation the value should be less than $0.05(\mathrm{P}<0.05)$ because 
this show the significantly relationship between the variables. Through this information, in the above data the $\mathrm{p}$ value is .000 that illustrates, there is significant relationship between product quality and customer loyalty. Here second hypothesis is approved. Now, from the information of above table the $\mathrm{p}$ value is less than $.05(\mathrm{P}<0.05)$ that shoes the significance level between variables and in this study here the $\mathrm{p}$ value is .000 that tells in fully, there is significant connection between awareness and customer loyalty and this support to third hypothesis of this research.

Table3: Model Summary

\begin{tabular}{|cc|c|c|c|}
\hline Predictors & $\mathbf{R}$ & $\mathbf{R}^{2}$ & Adjusted $\mathbf{R}^{\mathbf{2}}$ \\
\hline H1 & Service Quality & 0.507 & 0.77 & 0.255 \\
\hline H2 & Product Quality & 0.260 & 0.068 & 0.064 \\
\hline H3 & Awareness & 0.217 & 0.047 & 0.044 \\
\hline
\end{tabular}

Dependent variable: Customer Loyalty

Table 4: Coefficients

\begin{tabular}{|l|l|l|l|l|l|}
\hline Model & \multicolumn{2}{|l|}{$\begin{array}{l}\text { Unstandardized } \\
\text { Coefficients }\end{array}$} & $\begin{array}{l}\text { Standardized } \\
\text { Coefficients }\end{array}$ & t & \\
\hline & B & Std. Error & Beta & & \\
\hline 1.(Constant) & 1.539 & 1.047 & & 1.469 & .143 \\
Service Quality & 0.129 & 0.013 & 0.507 & 10.162 & $.000^{* * *}$ \\
\hline 2.(Constant) & 8.354 & .820 & & 10.185 & $.000^{* * *}$ \\
Product Quality & 0.202 & .043 & .260 & 4.649 & $.000^{* * *}$ \\
\hline 3.(Constant) & 9.263 & .757 & & 12.231 & $.000^{* * *}$ \\
Awareness & .187 & .049 & .217 & 3.830 & $.000^{* * *}$ \\
\hline
\end{tabular}

${ }^{*} \mathrm{p}<0.05,{ }^{* *} \mathrm{p}<0.01{ }^{* * *} \mathrm{p}<0.001$

\subsection{Result of regression analyses of Mediation (Customer satisfaction)}

Table 5: Model Summary

\begin{tabular}{|c|c|c|c|c|}
\hline \multicolumn{2}{|c|}{ Model } & $\mathbf{R}$ & $\mathbf{R}^{2}$ & Adjusted R $^{2}$ \\
\hline & 1 & $.507^{\mathrm{a}}$ & .257 & .255 \\
\hline \multicolumn{2}{|c|}{2} & $.722^{\mathrm{b}}$ & .522 & .519 \\
\hline $\mathrm{H} 5$ & 1 & $.260^{c}$ & .068 & .064 \\
\hline \multicolumn{2}{|c|}{2} & $.720^{\mathrm{d}}$ & .518 & .514 \\
\hline H6 & 1 & $.165^{\mathrm{e}}$ & .027 & .024 \\
\hline \multicolumn{2}{|c|}{2} & $.666^{\mathrm{f}}$ & .444 & .439 \\
\hline
\end{tabular}

a. Predictors: (Constant), Service Quality, b. Predictors: (Constant), Service Quality, Customer Satisfaction, c. Predictors: (Constant), Product Quality, d. Predictors: (Constant), Product Quality, Customer Satisfaction, e. Predictors: (Constant), Awareness, f. Predictors: (Constant), Awareness, Customer Satisfaction, g. Dependent Variable: Customer_Loyalty

The value of $\mathrm{R}$ square is 52.2 percent $\left(\mathrm{R}^{2}=.522\right)$ that means the impact of service quality is 52.2 percent on customer loyalty through customer satisfaction. The $\mathrm{R}$ square value is $51.8\left(\mathrm{R}^{2}=.518\right)$ that show the impact of product quality is 51.8 percent on customer loyalty 
through customer satisfaction. Awareness does not generate customer satisfaction. In above output indicate that $\mathrm{H} 4$ and $\mathrm{H} 5$ are approved and $\mathrm{H} 6$ is rejected.

Table 6: Coefficients

\begin{tabular}{|c|c|c|c|c|c|}
\hline \multirow[t]{2}{*}{ Model } & \multicolumn{2}{|c|}{$\begin{array}{l}\text { Unstandardized } \\
\text { Coefficients }\end{array}$} & $\begin{array}{c}\text { Standardized } \\
\text { Coefficients }\end{array}$ & \multirow[t]{2}{*}{$\mathbf{t}$} & \multirow{2}{*}{ Sig. } \\
\hline & B & Std. Error & Beta & & \\
\hline 1.(Constant) & 1.539 & 1.047 & & 1.469 & .143 \\
\hline Service Quality & 0.129 & 0.013 & 0.507 & 10.162 & $.000 * *$ \\
\hline (Constant) & 1.796 & .842 & & 2.133 & $.034 *$ \\
\hline Service Quality & .033 & .013 & .131 & 2.629 & $.009 *$ \\
\hline Customer satisfaction & .648 & .051 & 637 & 12.814 & $.000 * * *$ \\
\hline 2.(Constant) & 8.354 & .820 & & 10.185 & $.000 * * *$ \\
\hline Product Quality & 0.202 & .043 & .260 & 4.649 & $.000 * * *$ \\
\hline (Constant) & 2.602 & .685 & & 3.801 & $.000 * * *$ \\
\hline Product Quality & .067 & .032 & .087 & 2.088 & $.038 *$ \\
\hline Customer Satisfaction & .705 & .042 & 693 & 16.648 & $.000 * * *$ \\
\hline 3.(Constant) & 9.263 & .757 & & 12.231 & $.000 * * *$ \\
\hline Awareness & .187 & .049 & .217 & 3.830 & $.000 * * *$ \\
\hline (Constant) & 3.394 & .727 & & 4.667 & $.000 * * *$ \\
\hline Awareness & .050 & .046 & .051 & 1.089 & .277 \\
\hline Customer Satisfaction & .685 & .049 & .655 & 13.866 & $.000 * * *$ \\
\hline
\end{tabular}

The $\mathrm{p}$ value of service quality is .009 that lesser than .05 means there is significant connection between service quality and customer loyalty through customer satisfaction. The beta value shows that also there is positive relationship between service quality and customer loyalty by customer satisfaction. The $\mathrm{p}$ value is .038 that shows that there is significant relationship between product quality and customer loyalty through customer satisfaction. The $\mathrm{p}$ value of awareness is .227 that greater than .05 means there is insignificant relationship between awareness and customer loyalty through customer satisfaction. The beta value shows that also there is positive affiliation between service quality and customer loyalty through customer satisfaction.

\subsection{Result of regression analyses of customer satisfaction for customer loyalty}

Table 7: Model Summary

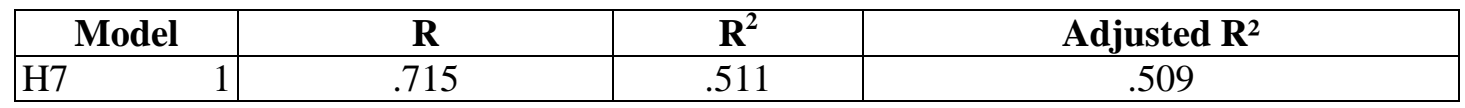


The $\mathrm{R}$ square value is $51.1\left(\mathrm{R}^{2}=.511\right)$ that show the impact of customer satisfaction is 51.1 percent on customer loyalty. It means 51.1 percent change in customer loyalty due to change in customer satisfaction. And $\mathrm{H} 7$ is approve in this study.

Table 8: Coefficients

\begin{tabular}{|c|c|c|c|c|c|}
\hline \multirow{2}{*}{ Model } & \multicolumn{2}{|c|}{$\begin{array}{c}\text { Unstandardized } \\
\text { Coefficients }\end{array}$} & $\begin{array}{c}\text { Standardized } \\
\text { Coefficients }\end{array}$ & \multirow{2}{*}{ Sig. } \\
\cline { 2 - 4 } & B & Std. Error & Beta & & \\
\hline 3.(Constant) & 3.604 & .491 & & 7.340 & .000 \\
Customer Satisfaction & .727 & .041 & .715 & 17.633 & .000 \\
\hline
\end{tabular}

*p $<0.05, * * \mathrm{p}<0.01 * * * \mathrm{p}<0.001$

The $\mathrm{p}$ value is .000 that shows, there is significant relationship between customer satisfaction and customer loyalty. Beta value $(\beta)$ is .717 indicate that there is positive impact of customer satisfaction on customer loyalty.

\subsection{Result of regression analyses of Moderation}

Table 9: Model Summary

\begin{tabular}{|cc|c|c|}
\hline \multicolumn{2}{|c|}{ Predictors } & $\mathbf{R}$ & $\mathbf{R}^{\mathbf{2}}$ \\
\hline H8 & 1 & .5248 & 0.2754 \\
\hline H9 & 2 & 0.321 & 0.103 \\
\hline H10 & 3 & .311 & 0.097 \\
\hline
\end{tabular}

In above table result $\mathrm{R}^{2}=.5248$ indicate the religiosity significantly moderate the relationship of customer satisfaction and service quality. H8 is accepted in this result output. Religiosity does not significantly moderate the relationship of awareness, and product quality with customer satisfaction.

Table 10: Coefficients

\begin{tabular}{|c|c|c|c|c|c|}
\hline \multirow{2}{*}{ Model } & \multicolumn{2}{|c|}{$\begin{array}{c}\text { Unstandardized } \\
\text { Coefficients }\end{array}$} & $\begin{array}{c}\text { Standardized } \\
\text { Coefficients }\end{array}$ & \multirow{2}{*}{ Sig. } & \\
\cline { 2 - 4 } & B & Std. Error & Beta & & \\
\hline 1.(Constant) & 1.539 & 3.399 & & 2.9779 & $.0031^{* *}$ \\
Service Quality & 0.129 & .04376 & 0.343 & .3589 & $0.03 *$ \\
\hline Religiosity & 1.796 & .0012 & 0.155 & 2.133 & $.030^{*}$ \\
\hline Int_SQ_RLG & .045 & .013 & .131 & -2.3226 & $0.02^{*}$ \\
\hline 2.(Constant) & 1.629 & 5.541 & & .294 & .769 \\
Product Quality & .354 & .302 & .464 & 1.173 & .242 \\
\hline Religiosity & .175 & .141 & .375 & 1.242 & .215 \\
\hline Int_PQ_RLG & -.004 & .008 & -.302 & -.589 & .557 \\
\hline 3.(Constant) & .560 & 5.530 & & .101 & .919 \\
Awareness & .519 & .368 & .613 & 1.40 & .160 \\
\hline Religiosity & .214 & .139 & .458 & 1.536 & .126 \\
\hline Int_Awareness_RLG & -.008 & .009 & -.512 & -.919 & .359 \\
\hline *p $<0.05, * *$ p $<0.01 * * * p<0.001$ & & & & &
\end{tabular}


By using the Andrew Hayes model 7 moderation method because my research model meets with hayes model no. 7 in SPSS and this is also the novelty of my study because we used hayes process for the sake of excellent and valid results and through this way the $p$ value shows that religiosity moderates in the middle of service quality and customer satisfaction. This process withdraw accurate results and latest method. When better service quality is provided by the organization to the client then automatically client satisfaction increase and through the effect of religious factor involving, there is basically edge to this system because majority Muslims want to meet the Sharia compliance and this done through using Islamic banking system instead of conventional banking. The $\mathrm{p}$ value indicate that religiosity has not moderate between the product quality and customer satisfaction.

\section{Conclusion and Recommendations}

Now, in present the Islamic banking system and conventional banking system are the direct competitors in Pakistan. Islamic banking sector of Pakistan is growing day by day and become the prominent banking system. The findings of our research are; Service quality and product quality have significantly relationship to the customer satisfaction and customer loyalty in Pakistani Islamic banks of south Punjab. To support our study results matches to (Kashif, M., Abdur Rehman, M., (2016) and Atiyah, L. (2016) have resulted that service quality and product quality have positively influence to the customer satisfaction and loyalty. The people of south Punjab through my study, they are not sure about the Islamic banking products like Murahabah, Takaful. They cannot distinguish between Islamic banking system and conventional banking system products due to the lack of knowledge.

The studies have done in Pakistan only on service quality to the association on customer satisfaction and customer loyalty. Now, we have applied our model with together the three best unique strategies to attract the customer for satisfaction and loyalty these all strategies are very unique to inspect the customer gratification and loyalty in Islamic banking system. No study is done with this model like moderation impact on these three factors; service quality, product quality and awareness and customer satisfaction. By using Andrew hayes model no. 7 the religiosity factor only moderates with service quality and customer satisfaction because there is less awareness due to this factor religiosity did not impact between awareness and customer satisfaction.

Our research results implicate in Islamic banking sector to help them while taking the decisions to set up for any new strategies. Our recommendations for customers and also bank staff to have best knowledge should mandatory Islamic banking sector is required to also 
Pakistan Journal of Humanities and Social Sciences, 7(4), 2019

aware their own staff that motivates the customers through their best command on the information of products and also they required to have best knowledge about religiosity.

Through our study, in future the researcher can expand it on country level and choose any other sampling instead of convenient sampling and furthermore they can explore with combine study Islamic and conventional banking system. Moreover, the future research on to add some new helping variables that will cause of satisfied the customer like; bank location, awareness to staff, and Innovation in products are the variables that can be studied in future.

\section{References}

Abou-Youssef, M. M. H., Kortam, W., Abou-Aish, E., \& El-Bassiouny, N. (2015). Effects of religiosity on consumer attitudes toward Islamic banking in Egypt. International Journal of Bank Marketing, 33(6), 786-807.

Ago, G., Suharno, S. M., \& Hariyadi, S. (2015). Effect Of Product Quality Perception, Trust, and Brand Image on Generic Drug Buying Decision and Consumer Satisfaction of Hospital Patients in East Kalimantan. European Journal of Business and Management, 7(14).

Ahmad, S. A., \& Al-Aidaros, A. H. (2017). CUSTOMER AWARENESS AND SATISFACTION OF LOCAL ISLAMIC BANKS IN MALAYSIA. IJIB, 2(2), 37.

Alnaser, F., Ghani, M., \& Rahi, S. (2018). Service quality in Islamic banks: The role of PAKSERV model, customer satisfaction and customer loyalty. Accounting, 4(2), 6372.

Alsayyed, N. M., Suifan, T. S., \& Alawneh, A. R. (2015). Exploring the effect of perceived service quality on customer's satisfaction: A study of banking sector in Jordan. Journal of Management Research, 7(1), 122-138

Amin, M., Isa, Z., \& Fontaine, R. (2013). Islamic banks: Contrasting the drivers of customer satisfaction on image, trust, and loyalty of Muslim and non-Muslim customers in Malaysia. International Journal of Bank Marketing, 31(2), 79-97.

Amin, M., Isa, Z., and Fontaine, R. (2011), "The role of customer satisfaction in enhancing Customer loyalty in Malaysian Islamic banks", The Service Industries Journal, Vol. 31 No.

9, pp. 1519-1532.

Ashraf, M. G. (2014). Include the Position of Islamic Banking, Service Quality, Satisfaction, Trust and Loyalty in the Context of an Integrated Model for Islamic Finance. European Journal of Business and Management, 6(17), 156-169.

Atiyah, L. (2016). PRODUCT'S QUALITY AND ITS IMPACT ON CUSTOMER SATISFACTION A FIELD STUDY IN DIWANIYAH DAIRY FACTORY. In Proceedings of the INTERNATIONAL MANAGEMENT CONFERENCE ( Vol. 10, No. 1, pp. 57-65). Faculty of Management, Academy of Economic Studies, Bucharest, Romania.

Bashir, M. S. (2013). Analysis of customer satisfaction with the Islamic banking sector: case of Brunei Darussalam. Asian Journal of Business and Management Sciences, 2(10), $38-50$.

Bowman, N. A., Denson, N., \& Park, J. J. (2016). Racial/cultural awareness workshops and post-college civic engagement: A propensity score matching approach. American Educational Research Journal, 53(6), 1556-1587 
Buchari, I., Rafiki, A., \& Al Qassab, M. A. H. (2015). Awareness and attitudes of employees towards islamic banking products in Bahrain. Procedia Economics and Finance, 30, $68-78$.

Chalotra, V. (2012). Customer Satisfaction Regarding Small Scale Industries Products. Amity Global Business Review, 7.

Chai, K. H., Ding, Y., \& Xing, Y. (2009). Quality and customer satisfaction spillovers in the mobile phone industry. Service Science, 1(2), 93-106.

Doraisamy, B., Shanmugam, A., \& Raman, R. (2011). A STUDY ON CONSUMERS'PERFERENCES OF ISLAMIC BANKING PRODUCTS AND SERVICES IN SUNGAI PETANI. Academic Research International, 1(3), 290

Ennew, C., Waite, N., \& Waite, R. (2013). Financial services marketing: An international guide to principles and practice. Routledge.

Faridah Syed Alwi, S., \& Melewar, T. C. (2013). Branding in the Asian context: a Malaysian perspective. Asia Pacific Journal of Marketing and Logistics, 25(2), 287-297

Golder, P. N., Mitra, D., \& Moorman, C. (2012). What is quality? An integrative framework of processes and states. Journal of Marketing, 76(4), 1-23.

Islamic Banking Bulletin Islamic Banking Department State Bank of Pakistan December 2017

Jahanshahi, A. A., Gashti, M. A. H., Mirdamadi, S. A., Nawaser, K., \& Khaksar, S. M. S. (2011). Study the effects of customer service and product quality on customer satisfaction and loyalty. International Journal of Humanities and Social Science, 1(7), 253-260.

Janahi, M. A., \& Al Mubarak, M. M. S. (2017). The impact of customer service quality on customer satisfaction in Islamic banking. Journal of Islamic Marketing, 8(4), 595-604

Jeong, Y., \& Lee, Y. (2010). A study on the customer satisfaction and customer loyalty of furniture purchaser in on-line shop. Asian Journal on Quality, 11(2), 146-156.

Jiang, L., Jun, M., \& Yang, Z. (2016). Customer-perceived value and loyalty: how do key service quality dimensions' matter in the context of B2C e-commerce? Service Business, 10(2), 301-317.

Jing, Z., Pitsaphol, C., \& Shabbir, R. (2014). The Influence of Brand Awareness, Brand Image And Perceived Qualityon Brand Loyalty: A Case Study Of Oppo Brand In Thailand. Interdisciplinary journal of contemporary research in business, 5(12).

Jinjiri Ringim, K. (2014). Perception of Nigerian Muslim account holders in conventional banks toward Islamic banking products. International Journal of Islamic and Middle Eastern Finance and Management, 7(3), 288-305

Kaabachi, S., \& Obeid, H. (2016). Determinants of Islamic banking adoption in Tunisia: empirical analysis. International Journal of Bank Marketing, 34(7), 1069-1091.

Kashif, M., Wan Shukran, S. S., Rehman, M. A., \& Sarifuddin, S. (2015). Customer satisfaction and loyalty in Malaysian Islamic banks: a PAKSERV investigation. International Journal of Bank Marketing, 33(1), 23-40

Kashif, M., Abdur Rehman, M., \& Pileliene, L. (2016). Customer perceived service quality and loyalty in Islamic banks: A collectivist cultural perspective. The TQM Journal, 28(1), 62-78.

Kassim, N. and Abdullah, N. (2010), "The effect of perceived service dimension on customer satisfaction, trust, loyalty in e-commerce settings: a cross-cultural analysis", Asia Pacific Journal of Marketing and Logistics, Vol. 22 No. 3, pp. 351-371.

Kitapci, O., Taylan Dortyol, I., Yaman, Z., \& Gulmez, M. (2013). The paths from service quality dimensions to customer loyalty: An application on supermarket customers. Management Research Review, 36(3), 239-255. 
Pakistan Journal of Humanities and Social Sciences, 7(4), 2019

Ladhari, R., Souiden, N., \& Ladhari, I. (2011). Determinants of loyalty and recommendation: The role of perceived service quality, emotional satisfaction and image. Journal of Financial Services Marketing, 16(2), 111-124.

Manzoor, M. M., Aqeel, M., \& Sattar, A. (2010). Factors paving the way towards islamic banking in pakistan. World Academy of Science, Engineering and Technology, 66, 1677-1683

Majeed, M. T., \& Zainab, A. (2017). How Islamic is Islamic banking in Pakistan? International Journal of Islamic and Middle Eastern Finance and Management, 10(4), 470-483

Marković, S., Jelena, D., \& Katušić, G. (2015, January). Service Quality Measurement in Croatian Banking Sector: Application of SERVQUAL Model. In MIC 2015: Managing Sustainable Growth.

Mohamad, H. A. D., Ab Yazid, M. S., Khatibi, A., \& Azam, S. F. (2017). SERVICE QUALITY, CUSTOMER SATISFACTION AND CUSTOMER LOYALTY OF THE HOTEL INDUSTRY IN UNITED ARAB EMIRATES (UAE): A MEASUREMENT MODEL. European Journal of Management and Marketing Studies.

Mohiuddin, Z. A., Begum, R., \& Rizvi, F. Z. (2018). Ineffective Awareness of Islamic Banking Products as A Root Cause of Reluctance for the Same by Corporate Customers: A Case Study of MCB-NIB Merger in Pakistan. European Scientific Journal, ESJ, 14(13).

Moon, S. Y., Philip, G. C., \& Moon, S. (2011). The effects of involvement on e-satisfaction models. Services Marketing Quarterly, 32(4), 332-342.

Rahman, M. (2014). FACTORS AFFECTING CUSTOMER SATISFACTION IN MOBILE TELECOMMUNICATION INDUSTRY IN BANGLADESH. Business, Management \& Education/Verslas, Vadyba ir Studijos, 12(1).

Rahi, S., \& Ghani, M. (2016). Internet banking, customer perceived value and loyalty: The role of switching costs. J Account Mark, 5(188), 2.

Rammal, H. G., \& Zurbruegg, R. (2016). Awareness of Islamic banking products among Muslims: The case of Australia. In Islamic Finance (pp. 141-156). Palgrave Macmillan, Cham

Rasheed, H., \& Wang, A. (2012). An Evaluation of Bank Customer Satisfaction in Pakistan, Case of Conventional Banks. International Journal of Business and Social Science, 3(16).

Saini, Y., Bick, G., \& Abdulla, L. (2011). Consumer awareness and usage of Islamic banking products in South Africa. South African Journal of Economic and Management Sciences, 14(3), 298-313.

Saqib, L., Farooq, M. A., \& Zafar, A. M. (2016). Customer perception regarding Sharī 'ah compliance of Islamic banking sector of Pakistan. Journal of Islamic Accounting and Business Research, 7(4), 282-303.

Souiden, N., \& Jabeur, Y. (2015). The impact of Islamic beliefs on consumers' attitudes and purchase intentions of life insurance. International Journal of Bank Marketing, 33(4), 423-441.

Usman, H., Tjiptoherijanto, P., Balqiah, T. E., \& Agung, I. G. N. (2017). The role of religious norms, trust, importance of attributes and information sources in the relationship between religiosity and selection of the Islamic bank. Journal of Islamic Marketing, 8(2), 158-186

Wahyuni, S., \& Fitriani, N. (2017). Brand religiosity aura and brand loyalty in Indonesia Islamic banking. Journal of Islamic Marketing, 8(3), 361-372. 
Wilson, A., Zeithaml, V. A., Bitner, M. J., \& Gremler, D. D. (2012). Services marketing: Integrating customer focus across the firm (No. 2nd Eu). McGraw Hill.

Xu, L., Blankson, C., \& Prybutok, V. (2017). Relative contributions of product quality and service quality in the automobile industry. Quality Management Journal, 24(1), 21 36.

Yousaf, S., \& Shaukat Malik, M. (2013). Evaluating the influences of religiosity and product involvement level on the consumers. Journal of Islamic Marketing, 4(2), 163-186.

Zeithaml, V. A., et al., (2011). Services Marketing: Integrating Customer Focus Across the Firm 5th edition, McGraw Hill, New Delhi. 